\title{
IDENTIFIKASI ZONA RESERVOAR PANAS BUMI BERDASARKAN ANALISIS FAULT FRACTURE DENSITY CITRA DIGITAL ELEVATION MODEL ALOS PALSAR DI GUNUNG RAJABASA
}

\section{IDENTIFICATION OF GEOTHERMAL RESERVOIR ZONE BASED ON FAULT FRACTURE DENSITY ANALYSIS OF DIGITAL ELEVATION MODEL ALOS PALSAR IMAGE IN MOUNT RAJABASA}

\author{
I Gede Boy Darmawan ${ }^{1,2}$, Dirga Ilham Fahlevi ${ }^{1}$, Muhammad Farhan Yassar ${ }^{1,2}$, \\ dan Fachri Aldi Pramudya ${ }^{1}$ \\ ${ }^{1}$ Jurusan Teknik Geofisika, Fakultas Teknik, Universitas Lampung \\ ${ }^{2}$ Tim Riset Unila Geoscience, Teknik Geofisika, Universitas Lampung \\ igedeboy@staff.unila.ac.id
}

\begin{abstract}
ABSTRAK
Gunung Rajabasa merupakan salah satu lapangan panas bumi di Sumatra yang belum dapat dieksploitasi hingga saat ini. Keberadaan manifestasi di daerah ini menjadi petunjuk keberadaan zona reservoar panas bumi. Penelitian ini bertujuan untuk mengidentifikasi zona permeabilitas tinggi berdasarkan analisis Fault Fracture Density (FFD) dan menganalisis keterkaitan antara karakteristik struktur jalur fluida panas bumi ke permukaan dengan lokasi zona reservoar panas bumi. Metode FFD dilakukan dengan menggunakan Citra Digital Elevation Model (DEM) ALOS PALSAR untuk memetakan kelurusan/lineament yang berasosiasi dengan zona patahan maupun rekahan khususnya di area manifestasi. Observasi struktur di lapangan dilakukan untuk mengkonfirmasi hasil FFD. Arah dominan dari struktur yang teridentifikasi sebagian selaras dan searah dengan sistem sesar Sumatra yaitu arah Barat Laut - Tenggara dan sebagian menunjukkan respons yang memotong sistem sesar utama. Selanjutnya, hasil analisis FFD menunjukkan keterkaitan yang cukup signifikan antara zona lemah (fracturing) dengan zona reservoar panas bumi yang ditunjukkan oleh pola densitas struktur tinggi pada zona upflow di manifestasi Way Belerang, sedangkan pada zona outflow di manifestasi mata air panas Gunung Botak berada pada densitas struktur yang rendah.
\end{abstract}

Kata kunci: Kelurusan, Manifestasi, Panas Bumi, Rajabasa, Reservoar

\section{ABSTRACT}

Mount Rajabasa is one of the geothermal fields in Sumatra that has not been exploited until now. The existence of manifestations in this area is an indication of the potential existence of geothermal reservoirs. This study aims to identify high permeability zones based on Fault Fracture Density (FFD) analysis and to analyze the relationship between the characteristics of the geothermal fluid path structure to the surface and the potential location of the geothermal reservoir. The FFD method is carried out using the Digital Elevation Model (DEM) ALOS PALSAR image to map the lineaments associated with fault zones and fractures, especially in the manifestation area. Field observations were made to confirm the FFD results. The dominant direction of the identified structures is partially aligned and in line with the Sumatra fault system, namely the northwest-southeast direction and partly shows a response that intersects the main fault system. Furthermore, the results of the FFD analysis show a significant relationship between the weak zone (fracturing) and the geothermal reservoir zone as indicated by the high structural density pattern in the upflow zone in the Way Sulfur manifestation, while the outflow zone in the hot springs of Mount Botak is at a low structural density.

Keywords: Geothermal, Lineament, Manifestations, Rajabasa, Reservoir 


\section{PENDAHULUAN}

Keberadaan manifestasi panas bumi di Gunung Rajabasa menandakan adanya potensi energi panas bumi di daerah ini. Manifestasi panas bumi berupa fumarol, kolam lumpur dan mata air panas muncul di bagian Utara dan Selatan kaki Gunung Rajabasa. Gunung Rajabasa saat ini, muncul di dalam cekungan kaldera PraRajabasa. Proses ini bersamaan dengan erupsi lereng dan gunungapi monogenesis, sebagai tahap terbentuknya kedua kerucut komposit. Gunungapi Pra-Rajabasa dan Rajabasa tersusun atas batuan berupa aliran lava, breksi gunungapi, dan tuf dengan komposisi basal sampai andesit (Bronto dkk., 2012).

Metode-metode eksplorasi di lapangan panas bumi ditujukan untuk menentukan kedalaman dan batas-batas reservoar sebagai sumber energi panas bumi yang akan dieksploitasi. Gambaran reservoar bawah permukaan yang akurat sangat diperlukan untuk menentukan posisi reservoar panas bumi (Darmawan dkk., 2015).

Penelitian ini difokuskan pada pemanfaatan citra ALOS PALSAR khususnya DEM ALOS PALSAR untuk mendeteksi kelurusan-kelurusan di permukaan yang mencerminkan struktur. Citra ini adalah citra radar yang diperoleh dari hasil perekaman pantulan balik gelombang mikro oleh obyek. Hasil dari perekaman citra radar tahan terhadap kondisi cuaca atmosfer bumi serta waktu perekaman dapat dilakukan pada siang maupun malam hari (Rosenqvist dkk., 2014). Kelebihan ini diharapkan dapat diterapkan untuk mendeteksi struktur permukaan dengan baik.

Metode Fault Fracture Density (FFD) merupakan metode sederhana yang digunakan untuk mengidentifikasi daerah panas bumi berdasarkan densitas kelurusan. Kelurusan ini diasumsikan berasosiasi dengan fault atau fracture sebagai zona lemah yang menjadi jalur pergerakan fluida dari reservoir ke permukaan dan muncul sebagai manifestasi seperti mata air panas atau fumarol.

Berdasarkan hal tersebut, penelitian ini dilakukan untuk menentukan zona permeabilitas tinggi di lokasi panas bumi Gunung Rajabasa berdasarkan analisis Fault Fracture Density (FFD) sebagai acuan dalam menganalisis keterkaitan antara karakteristik struktur sebagai zona lemah terhadap jalur fluida panas bumi ke permukaan. Analisis struktur ini ditujukan untuk mengidentifikasi lokasi zona reservoar panas bumi berdasarkan analisis zona lemah (fracturing). Diharapkan penelitian ini mampu memberikan informasi penting dalam program eksplorasi panas bumi di Gunung Rajabasa, sehingga dapat segera dieksploitasi menjadi sumber energi listrik yang baru dan terbarukan.

\section{GEOLOGI}

\section{Geologi Gunung Rajabasa}

Penelitian ini difokuskan pada lapangan panas bumi Gunung Rajabasa, yang terletak di Kabupaten Lampung Selatan, Provinsi Lampung. Lokasi penelitian berjarak kurang lebih $31 \mathrm{~km}$ dari pelabuhan Bakauheni. Berdasarkan pada Peta Geologi Regional, Gunung Rajabasa berada pada Formasi Satuan Gunungapi Muda (Qhv) tersusun dari lava berkomposisi andesit-basal, breksi dan tuf. Formasi Lampung (QTI) dan Andesit Tersier (Tpv) berada di sekelilingnya (Gambar 1) (Mangga dkk., 1993).

Adapun produk vulkanisme berumur Tersier yang tersusun oleh lava andesitik, menyebar dari Barat sampai Tenggara. Satuan ini merupakan satuan paling tua di area penelitian. Karakteristik aliran lava yang tersingkap mengindikasikan bahwa perkembangan satuan andesit ini cukup dekat dengan pusat erupsi. (Bronto dkk., 2012). Tidak ada sejarah erupsi yang terekam di Gunung Rajabasa, hanya terjadi peningkatan aktivitas vulkanik di tahun 1863 dan 1892 tetapi tidak sampai terjadi erupsi (Budiardjo dkk., 1995). Satuan 
Andesit (Tpv) terbentuk di lingkungan terestrial, memperlihatkan kekar lembar sangat kuat. Satuan ini berupa lava dengan komposisi andesit berwarna kelabu tersingkap segar, ditindih tidak selaras oleh Formasi Lampung serta terkekarkan kuat.

Formasi Lampung (QTI) diendapkan di lingkungan terestrial-fluvial, serta air payau yang menindih tak selaras satuan-satuan yang lebih tua dan ditindih tak selaras oleh endapan Kuarter. Sebarannya menjemari sampai lajur busur belakang. Batuan ini terdiri dari tuf berisi riolit dan dasit serta vulkanoklastika tufaan. Formasi batuan termuda dengan nama Satuan Gunungapi Muda (Qhv) mendominasi seluruh area Gunung Rajabasa. Formasi ini tersusun atas lava dengan komposisi andesit sampai basal, breksi dan tuf.

\section{Struktur Regional Gunung Rajabasa}

Secara tektonik dan topografi daerah penelitian ini sangat kompleks. Vulkanisme terkait subduksi yang terkenal di Indonesia salah satunya adalah keterjadian gunung api Kuarter yang berada di sepanjang busur Sunda dan Banda (Gambar 2). Adanya transisi dari depan ke subduksi miring di Selat Sunda diperkirakan sebagai daerah perluasan yang merupakan hasil gerak berarah barat laut dari irisan busur di antara parit dan Sistem Sesar Sumatra (Barber dkk., 2005).

Sesar kompleks dan banyak dijumpai
secara regional adalah sesar-sesar
berarah Barat Laut - Tenggara.
Sebarannya sangat luas dan panjang
masing-masing sesar mencapai $25-35$
km. Khususnya sesar banyak ditemukan di
Lajur Barisan, di bagian Barat Daya, tetapi
kemungkinan besar terdapat di bawah
runtunan penutup endapan Kuarter. Sesar-
sesar yang terpetakan di Lajur Barisan
mempunyai sejarah yang kompleks,
dibuktikan dengan gerakan-gerakan turun
dan berbalik. Secara tak resmi, sesar-sesar
utama ini disebut Sesar Lampung -
Panjang dan Menanga (Gambar 2). Selain
itu, sesar-sesar ini juga ditafsirkan sebagai
bagian maupun gabungan dari Sistem
Sesar Sumatra (Mangga dkk., 1993).

Sesar kompleks dan banyak dijumpai secara regional adalah sesar-sesar berarah Barat Laut - Tenggara. Sebarannya sangat luas dan panjang masing-masing sesar mencapai 25 - 35 $\mathrm{km}$. Khususnya sesar banyak ditemukan di Lajur Barisan, di bagian Barat Daya, tetapi kemungkinan besar terdapat di bawah runtunan penutup endapan Kuarter. Sesarsesar yang terpetakan di Lajur Barisan mempunyai sejarah yang kompleks, dibuktikan dengan gerakan-gerakan turun utama ini disebut Sesar Lampung Panjang dan Menanga (Gambar 2). Selain itu, sesar-sesar ini juga ditafsirkan sebagai Sesar Sumatra (Mangga dkk., 1993).

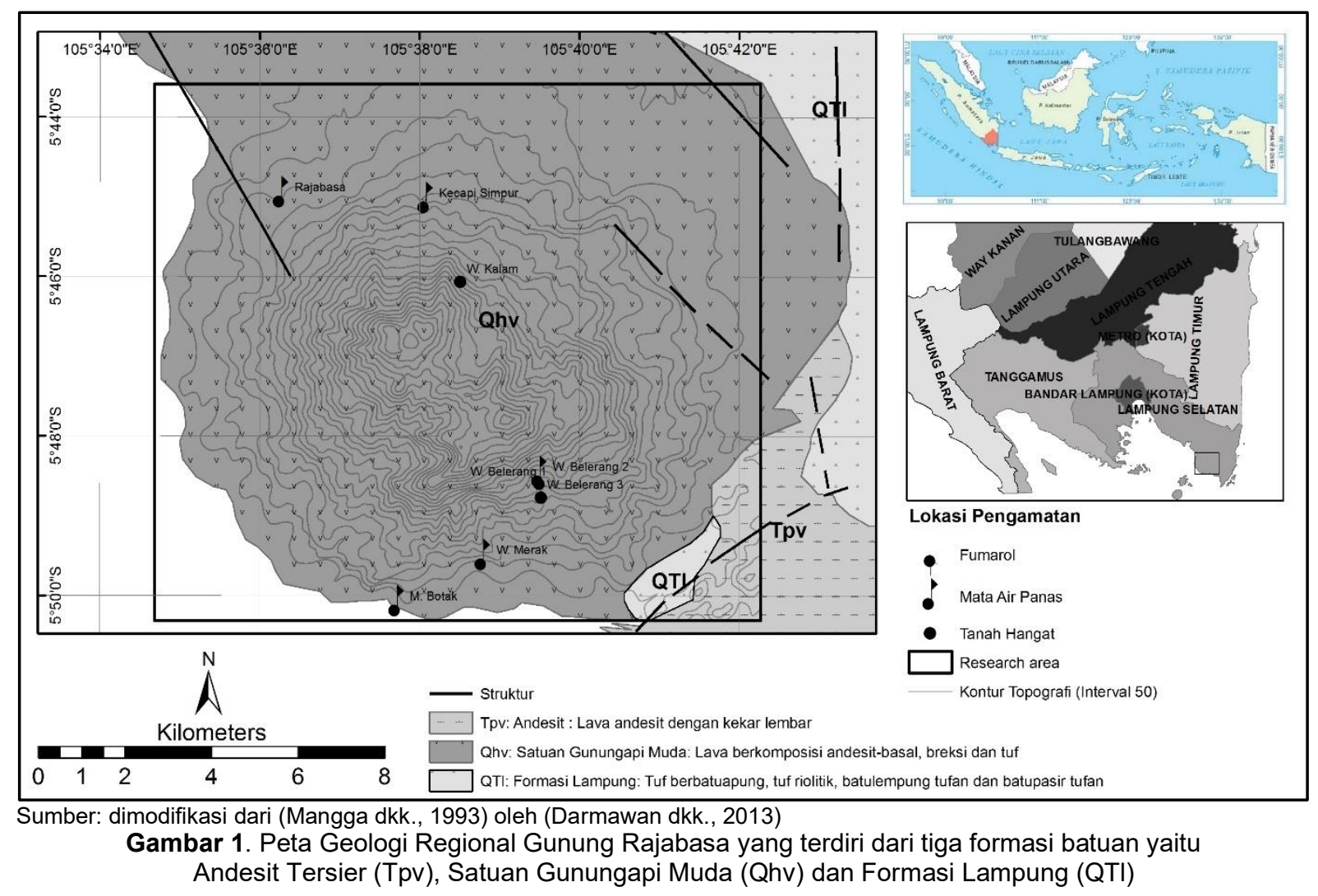




\section{MAKALAH ILMIAH}

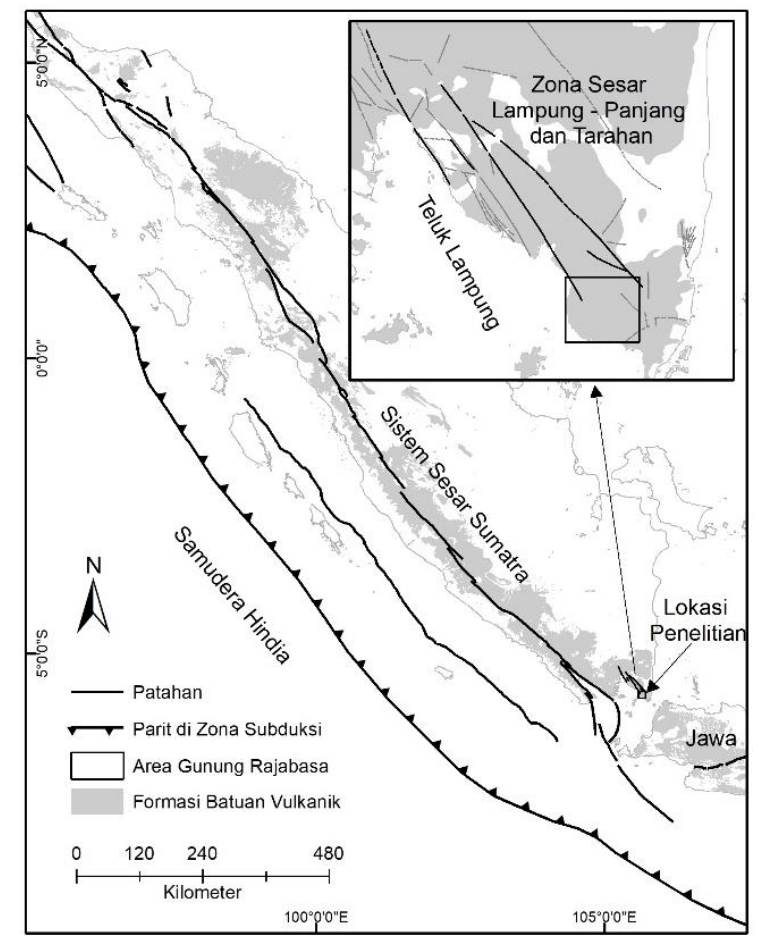

Sumber: dimodifikasi dari (Barber dkk., 2005; Mangga dkk., 1993)

Gambar 2. Peta struktur geologi regional Sumatra

\section{METODOLOGI}

Penelitian ini dilakukan dengan tahapan kegiatan meliputi pengolahan dan analisis data serta interpretasi hasil penelitian. Laboratorium Eksplorasi Geofisika Jurusan Teknik Geofisika dan di Lapangan Panas Bumi Gunung Rajabasa menjadi lokasi penelitian ini. Kegiatan pengolahan dan analisis data Citra DEM ALOS PALSAR menggunakan perangkat lunak berupa QGIS dan PCl Geomatics, sedangkan observasi langsung di lapangan menggunakan peralatan survei geologi.

\section{Citra ALOS PALSAR}

Penelitian ini menggunakan dua citra ALOS PALSAR yaitu citra dengan nomor scene AP_13982_FBD_F7070_RT1 dan scene AP_13982_FBD_F7060_RT1 (Gambar 3) yang diunduh secara akses terbuka dari https://search.asf.alaska.edu/. Kedua citra tersebut dimosaik untuk mendapatkan data khusus di area Gunung Rajabasa. Hasil mosaik yang telah diekstrak pada daerah Gunung Rajabasa kemudian di proses men jadi data DEM ALOS dengan resolusi spasial 12,5 meter.
ALOS (Advanced Land Observing Satellite) merupakan satelit milik Jepang yang merupakan satelit generasi lanjutan dari JERS-1 (Japanese Earth Resources Satellite-1) dan ADEOS (Advanced Earth Observing Satellite). ALOS diluncurkan di tahun 2006 dari stasiun peluncuran Tanegasima Space Center. Satelit ALOS memiliki periode orbit selama 46 hari dan mengorbit pada ketinggian $691 \mathrm{Km}$ (Rosenqvist dkk., 2014). Satelit ini juga memiliki tiga instrumen sensor berupa Panchromatic Remote-sensing Instrument for Stereo Mapping (PRISM) dengan resolusi 2,5 meter (along track), Advanced Visible and Near Infrared Radiometer type2 (AVNIR-2) dengan resolusi 10 meter, serta Phased-Array type L-band Synthetic Apeture Radar (PALSAR).

Untuk dapat bekerja dengan ketiga jenis sensor di atas, ALOS dilengkapi dengan dua teknologi yang lebih maju. Pertama teknologi yang mampu mengerjakan data dalam kapasitas yang sangat besar dengan kecepatan tinggi, dan selanjutnya kapasitas untuk menentukan posisi satelit dengan ketinggian yang lebih tepat. Satelit ALOS diluncurkan dengan tujuan untuk berkontribusi pada pemanfaatan seperti kartografi, penelitian sumber daya alam, pemantauan bencana alam, maupun pengamatan regional (Das dkk., 2015; Samsonov, 2010).

Sensor PALSAR yang dimiliki oleh ALOS merupakan sensor gelombang mikro aktif yang bekerja pada frekuensi L-Band. Sensor ini mampu melakukan observasi baik siang maupun malam hari, mampu menembus awan dan tanpa terpengaruh kondisi cuaca, sehingga informasi permukaan bumi dapat diperoleh setiap saat. Sensor ini juga merupakan pengembangan dari sensor SAR dari satelit pendahulunya yaitu satelit JERS-1. Sensor PALSAR pada ALOS memiliki tiga mode polarimetri yaitu single polarisation, dual polarisation, dan full polarimetry (Rosenqvist dkk., 2014; Shimada dkk., 2014; Whittle dkk., 2012). 

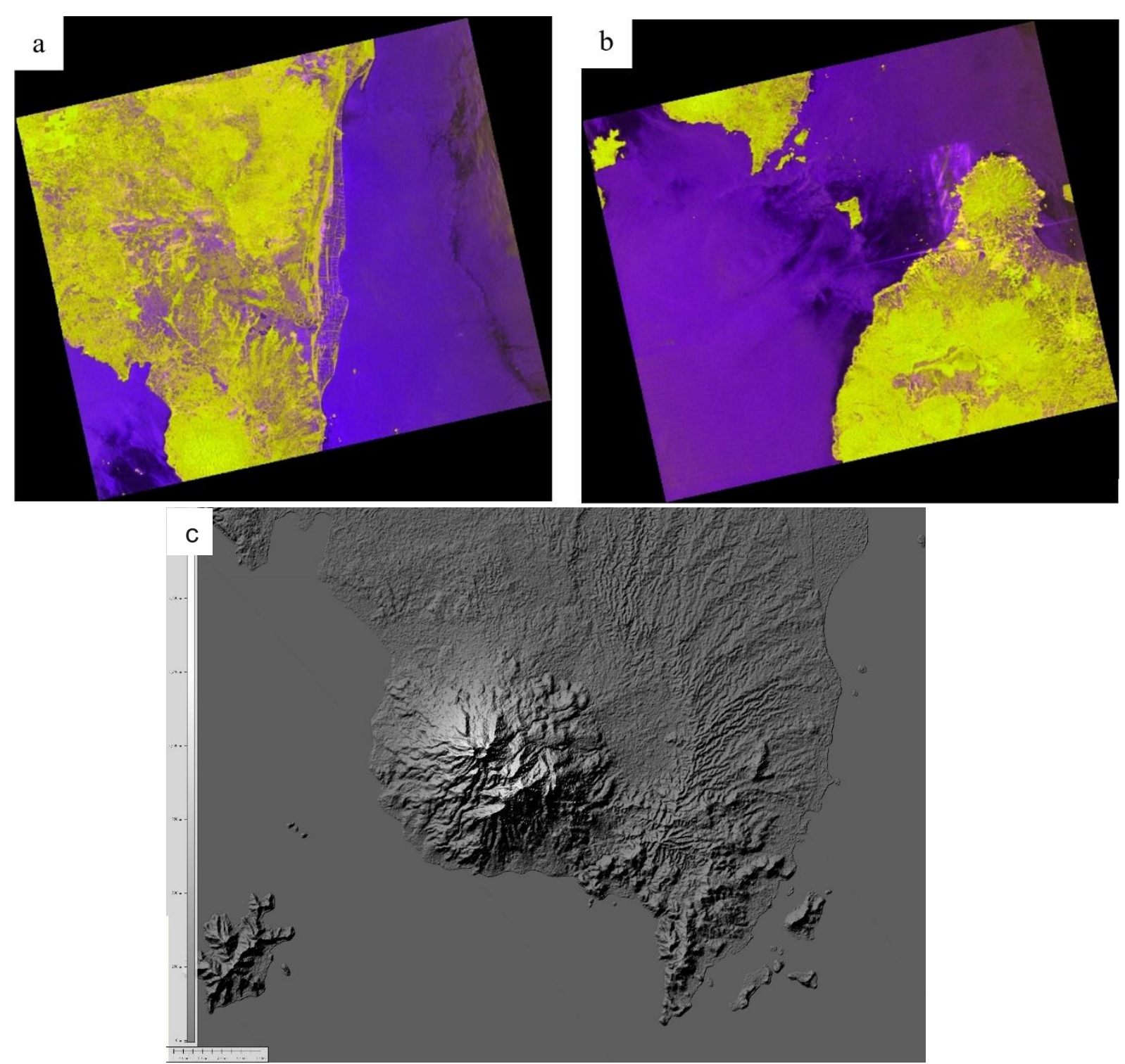

Gambar 3. (a) Citra ALOS PALSAR scene AP_13982_FBD_F7070_RT1 (b) dan AP_13982_FBD_F7060_RT1 (c) di area Gunung Rajabasa yang dimosaik dān shaded relief dengan menggunakan azimuth cahaya $315^{\circ}$, dan dengan ketinggian cahaya $45^{\circ}$ di daerah penelitian

\section{Metode Fault Fracture Density (FFD)}

Munculnya manifestasi panas bumi di permukaan umumnya disebabkan oleh perambatan panas dari bawah permukaan atau diakibatkan adanya rekahan-rekahan yang memungkinkan fluida panas bumi (uap dan air panas) untuk mengalir ke permukaan (Bujung dkk., 2011). Strukturstruktur yang menjadi jalur aliran fluida panas ke permukaan diasumsikan sebagai bidang lemah yang dapat menjadi salah satu petunjuk keberadaan zona uap/reservoar panas bumi (Suryantini dan Wibowo, 2010).
Metode Fault Fracture Density dapat digunakan untuk mengetahui kondisi struktur makro di suatu daerah, merupakan pengembangan dari analisis geospasial. Melalui penerapan pola dan perhitungan kerapatan garis lineasi pada citra satelit, metode ini mampu mengidentifikasi zonazona lemah. Fracture yang teridentifikasi dari hasil analisis FFD merupakan pola kelurusan, seperti pola kelurusan sungai maupun gawir yang diakibatkan oleh aktivitas sesar (Chemong dan Chenrai, 2013). 


\section{MAKALAH ILMIAH}

Pemetaan struktur berupa kelurusan/ lineament berdasarkan pada analisis citra satelit, salah satunya dapat dimanfaatkan untuk mengetahui zona mineralisasi emas di kawasan Australia bagian barat (Tripp dan Vearncombe, 2004), juga menggunakan FFD untuk eksplorasi panas bumi (Bujung dkk., 2011; Suryantini dan Wibowo, 2010), serta dapat dimanfaatkan sebagai salah satu metode yang membantu penentuan daerah rawan bencana gerakan tanah terhadap aktivitas tektonik di sekitarnya (Liu dan Mason, 2013).

\section{HASIL DAN PEMBAHASAN}

\section{HASIL}

Berdasarkan hasil pengolahan data citra ALOS PALSAR yang telah menghasilkan data DEM, maka proses ekstraksi lineament dapat dilakukan dengan mentransformasikan data DEM tersebut menjadi mode hillshade berdasarkan arah sudut penyinaran (azimuth) dan ketinggian. Untuk mendapatkan hasil yang optimal, ketinggian penyinaran yang digunakan adalah $45^{\circ}$ berlaku pada semua arah azimuth yang digunakan. Pada penelitian ini, telah digunakan empat arah sudut azimuth dalam ekstraksi lineament yaitu sudut $45^{\circ}, 135^{\circ}$, $225^{\circ}$ dan $315^{\circ}$.

\section{Densitas Struktur (FFD) Tiap Sudut Penyinaran}

Pada sudut penyinaran dan azimuth $45^{\circ}$, hasil ekstraksi lineament pada data DEM ALOS PALSAR di area Gunung Rajabasa didominasi oleh arah Barat Laut - Tenggara (Gambar 4). Secara kualitatif, densitas kelurusan hasil FFD yang mencirikan zona lemah di area Gunung Rajabasa bernilai tinggi di sekitar puncak gunung dan memiliki orientasi dominan pada arah Barat Laut sampai Tenggara dari puncak Gunung Rajabasa. Sementara untuk nilai densitas rendah tersebar di sekitar kaki Gunung Rajabasa khususnya di bagian Utara dan Barat dari puncak gunung.

Terdapat dua arah dominan pada 349 populasi kelurusan/lineament yaitu pada arah Barat Laut - Tenggara dan Barat Barat Laut - Timur Tenggara. Arah fractures dominan berdasarkan ekstraksi lineament ini selaras dengan arah struktur utama pada sistem sesar Sumatra yang berkembang di daerah ini. Sedangkan pada sudut penyinaran dan azimuth $135^{\circ}$, hasil ekstraksi lineament di area Gunung Rajabasa didominasi oleh arah Timur Laut Barat Daya (Gambar 5).

Berdasarkan Gambar 5, densitas kelurusan tinggi dari hasil FFD masih berada di sekitar puncak gunung. Kelurusan ini memiliki orientasi dominan khususnya ke arah Timur Laut dan Barat Daya. Sementara itu, densitas kelurusan bernilai rendah tersebar di sekitar kaki Gunung Rajabasa khususnya di bagian Utara dan Selatan dari puncak gunung.

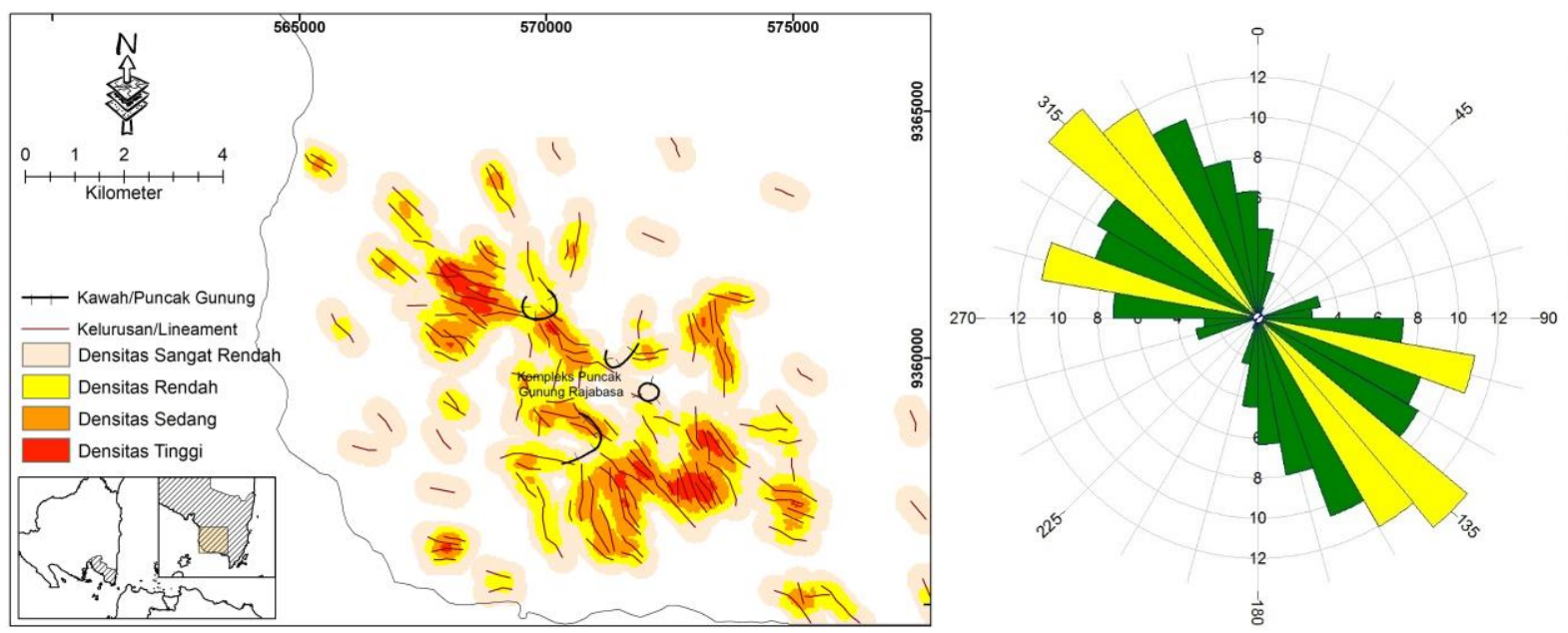

Gambar 4. Hasil ekstraksi lineament dan FFD pada data DEM ALOS PALSAR di area Gunung Rajabasa pada sudut azimuth $45^{\circ}$ 


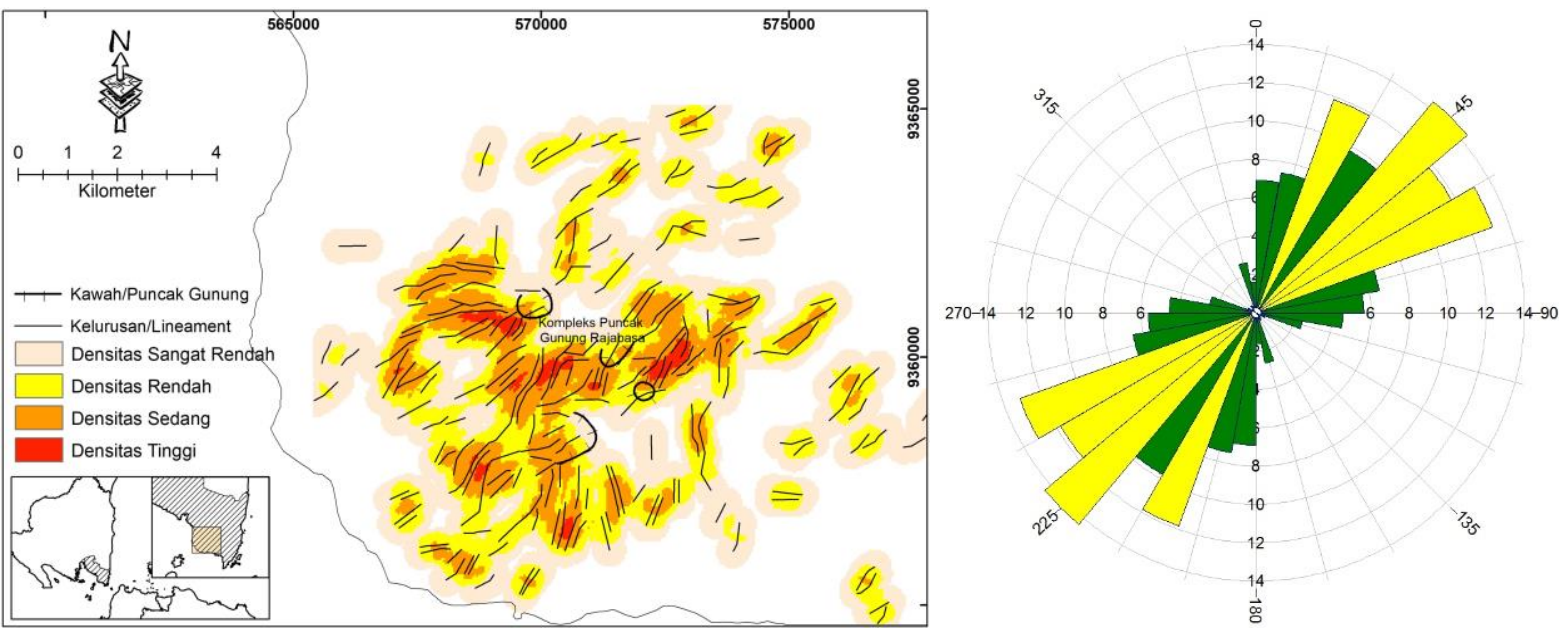

Gambar 5. Hasil ekstraksi lineament dan FFD pada data DEM ALOS PALSAR di area Gunung Rajabasa pada sudut azimuth $135^{\circ}$

Berdasarkan analisis lineament dengan menggunakan diagram mawar (rose diagram), terdapat tiga arah dominan pada 428 populasi kelurusan/lineament yaitu pada arah Timur Laut - Barat Daya, Timur Timur Laut - Barat Barat Daya dan Utaratimurlaut - Selatanbaratdaya. Arah fractures dominan berdasarkan ekstraksi lineament ini berlawanan dengan arah struktur utama pada sistem sesar Sumatra yang berkembang di daerah ini. Kondisi ini merupakan hal yang umum terjadi pada sistem sesar utama yang akan menimbulkan struktur yang memotong sistem sesar utama namun dengan radius yang lebih pendek.

Pada sudut penyinaran dan azimuth $225^{\circ}$, area Gunung Rajabasa didominasi oleh arah Barat Laut - Tenggara (Gambar 6). Hasil ini menunjukkan bahwa densitas kelurusan tinggi/zona lemah dominan berada di area puncak gunung serta memiliki orientasi yang dominan dari puncak Gunung Rajabasa ke arah Barat Laut, Selatan dan Tenggara. Sementara untuk nilai densitas rendah tersebar di sekitar kaki Gunung Rajabasa khususnya di bagian Barat Laut - Tenggara dan Selatan dari puncak gunung.

Terdapat tiga arah dominan pada 428 populasi kelurusan/lineament yaitu pada arah Barat Laut - Tenggara, Barat-Timur dan Utara Barat Laut - Selatan Tenggara. Arah fractures dominan berdasarkan ekstraksi lineament ini sebagian selaras dengan arah struktur utama pada sistem sesar Sumatra yang berkembang di daerah ini dan sebagian berlawanan. Kondisi ini umum terjadi pada sesar yang memotong sistem sesar utama dengan radius yang lebih pendek.

Kemudian pada sudut penyinaran dan azimuth $315^{\circ}$, hasil ekstraksi lineament didominasi oleh arah timur Laut - Barat Daya (Gambar 7). Secara kualitatif, densitas kelurusan hasil FFD yang mencirikan zona lemah di area Gunung Rajabasa bernilai tinggi di sekitar puncak gunung dan memiliki orientasi dominan pada puncak Gunung Rajabasa ke arah Timur, Barat dan Barat Daya. Sementara untuk nilai densitas rendah tersebar di sekitar kaki Gunung Rajabasa khususnya di bagian Timur ke Utara sampai Barat, dan Selatan sampai Tenggara dari puncak gunung.

Terdapat dua arah dominan pada 428 populasi kelurusan/lineament yaitu pada arah Timur Laut - Barat Daya dan Utara Timur Laut - Selatan Barat Daya. Arah fractures dominan berdasarkan ekstraksi lineament ini berlawanan dengan arah struktur utama pada sistem sesar Sumatra yang berkembang di daerah ini. 


\section{MAKALAH ILMIAH}

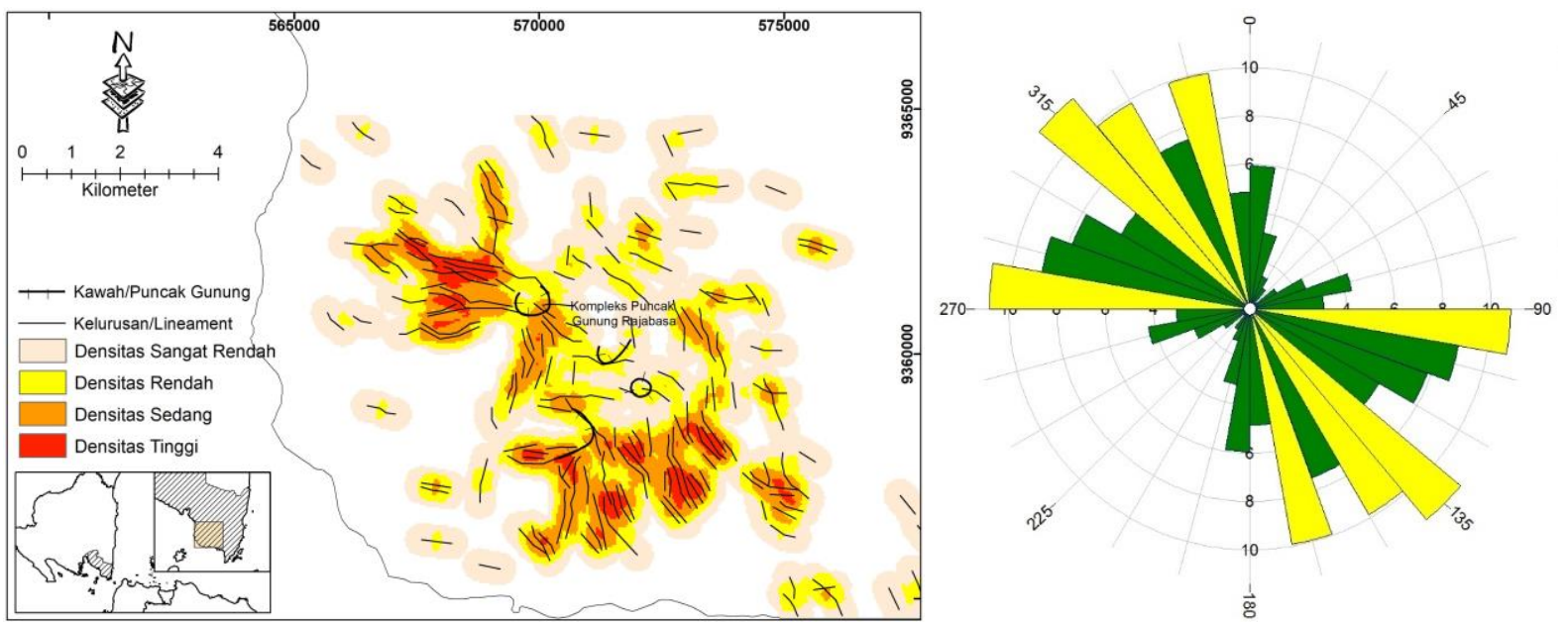

Gambar 6. Hasil ekstraksi lineament dan FFD pada data DEM ALOS PALSAR di area Gunung Rajabasa pada sudut azimuth $225^{\circ}$

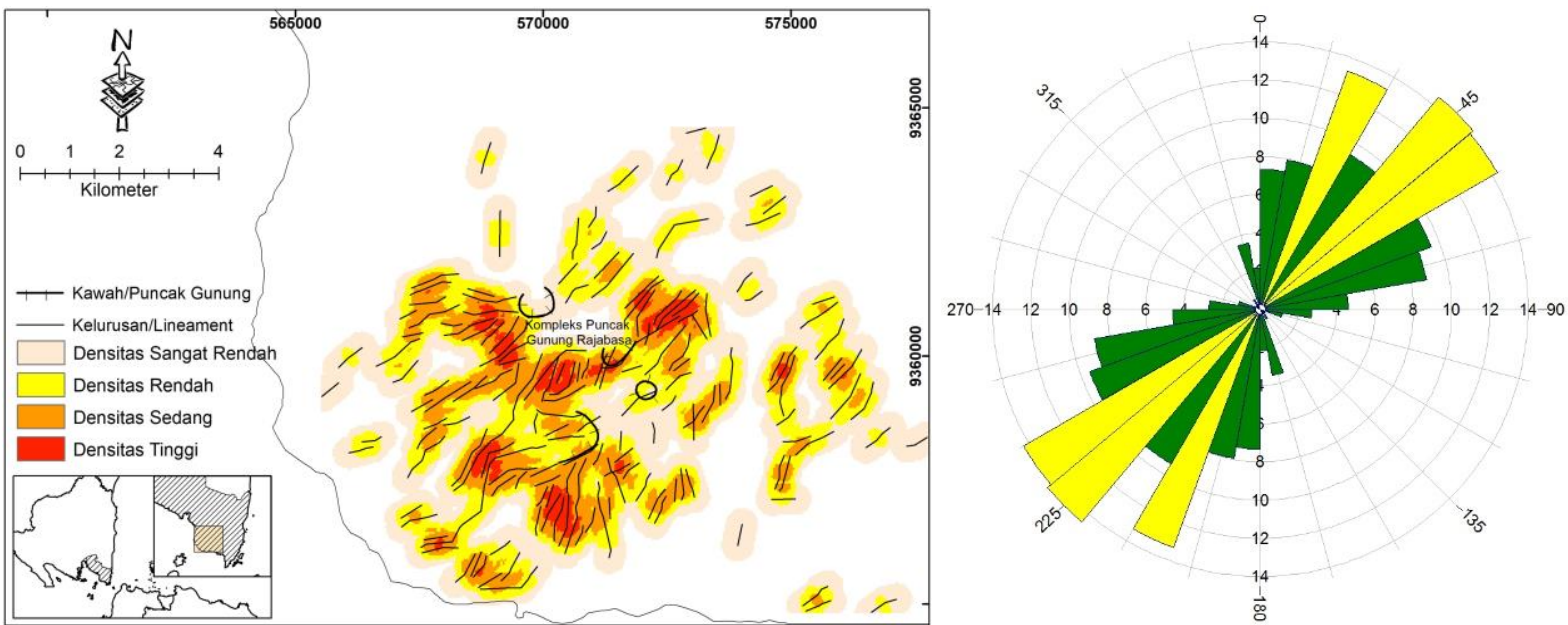

Gambar 7. Hasil ekstraksi lineament dan FFD pada data DEM ALOS PALSAR di area Gunung Rajabasa pada sudut azimuth $315^{\circ}$

\section{Observasi di Lapangan Panas Bumi Gunung Rajabasa}

Untuk mengetahui hubungan arah kelurusan dengan arah struktur yang berkembang di daerah penelitian, maka dilakukan integrasi antara kelurusan/ lineament hasil ekstraksi dari data DEM ALOS PALSAR yang dikorelasikan dengan pola struktur pada Peta Geologi Regional (Mangga dkk., 1993). Pola kelurusan yang berarah Barat Laut - Tenggara (NW-SE) merupakan pengaruh dari arah struktur sesar utama pada daerah penelitian. Sesar utama yang berarah Barat Laut - Tenggara tersebut merupakan sesar Lampung-
Panjang yang merupakan bagian dari Sistem Sesar Sumatra (Gambar 8).

Struktur geologi yang tampak di lapangan yaitu kekar di manifestasi air panas Gunung Botak yang berarah Timur Laut - Barat Daya dan Barat Laut - Tenggara. Kekar dengan arah Timur Laut - Barat Daya (NE-SW) tampak cukup jelas berada di manifestasi mata air panas Gunung Botak. Selain kekar dengan arah Timur Laut - Barat Daya juga terdapat kekar dengan arah Barat Laut Tenggara (NW-SE). Kekar dengan arah Barat Laut - Tenggara (NW-SE) juga tampak cukup jelas dan manifestasi air panas tepat berada pada struktur tersebut. 


\section{MAKALAH ILMIAH}

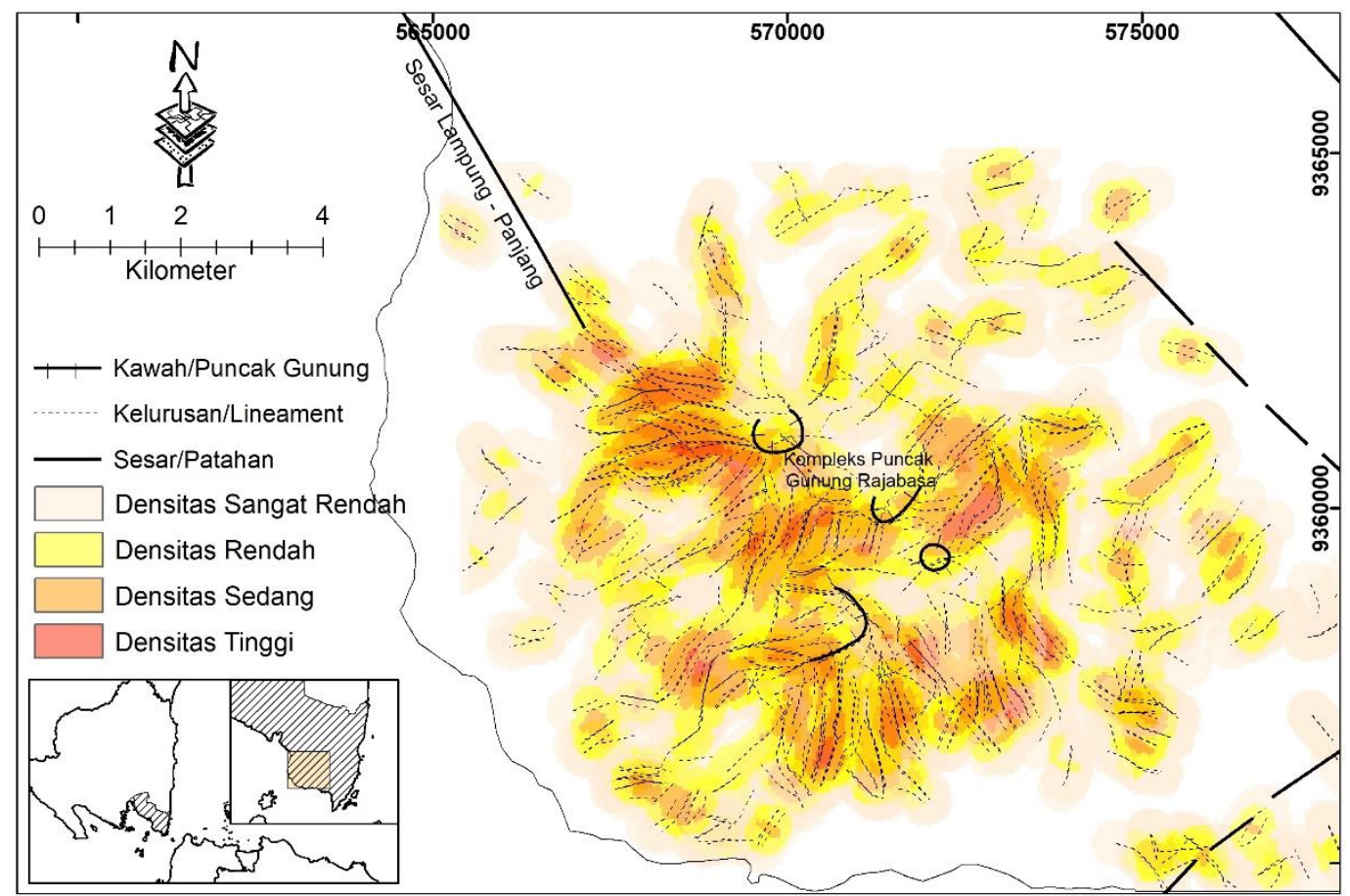

Gambar 8. Peta hubungan arah kelurusan dengan struktur patahan utama

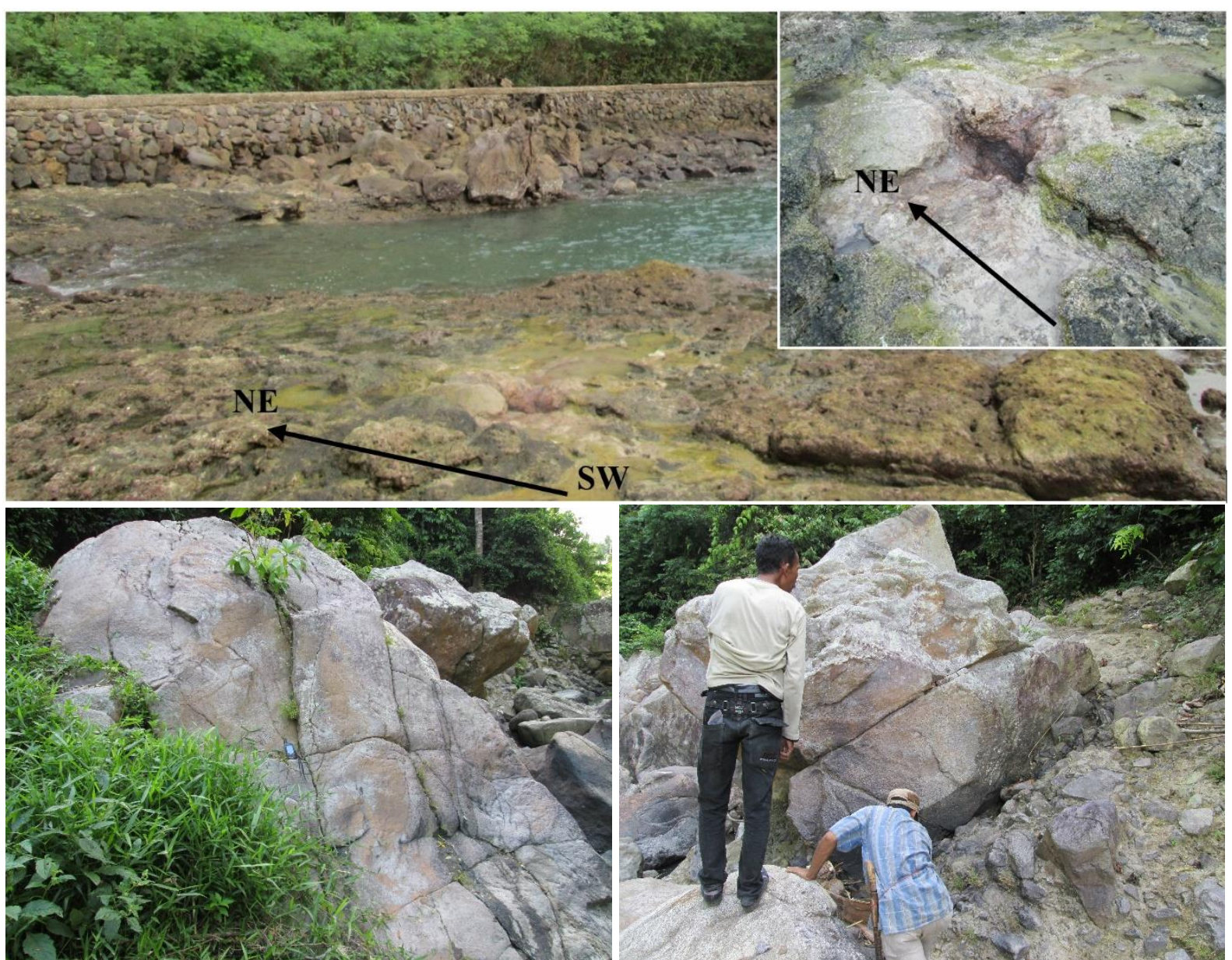

Gambar 9. Kekar berarah Timurlaut-Baratdaya (NE-SW) yang nampak di manifestasi mata air panas Gunung Botak (atas) dan Pola saling memotong antar kekar yang tersingkap pada batuan di area Gunung Rajabasa (bawah) 
Keberadaan struktur dengan arah Timur Laut - Barat Daya (NE-SW) dan Barat Laut - Tenggara (NW-SE) memberikan petunjuk mengenai sumber air panas yang ada di Gunung Botak (Gambar 9). Petunjuk ini akan bermanfaat saat menganalisis hubungan antara manifestasi permukaan dengan lokasi reservoar panas bumi.

Struktur-struktur yang tampak di area Gunung Rajabasa mencerminkan adanya zona fracture yang dapat digunakan untuk mengidentifikasi zona-zona lemah yang berkaitan dengan jalur naiknya fluida panas bumi ke permukaan sebagai manifestasi. Beberapa singkapan kekar di area Gunung Rajabasa menunjukkan pola yang saling memotong antara kekar utama dengan kekar lainnya yang lebih kecil. Pola ini mengkonfirmasi hasil ekstraksi lineament pada data DEM ALOS PALSAR yang menunjukkan adanya dominasi dua sampai tiga arah yang memotong atau berlawanan dengan arah Sistem Sesar Sumatra.

\section{PEMBAHASAN}

Berdasarkan hasil analisis pada ekstraksi lineament dan FFD terhadap 4 sudut azimuth yang diintegrasikan dengan hasil pengamatan struktur kekar di lapangan Gunung Rajabasa diperoleh pola penyebaran zona lemah (fracture zone) yang kemungkinan berkaitan dengan zona reservoar panas bumi. Dengan memanfaatkan teknik index overlay pada seluruh hasil analisis tersebut diperoleh peta sebaran densitas struktur (Fault Fracture Density)/FFD (Gambar 10).

Wilayah yang berada pada zona densitas sedang sampai densitas tinggi didominasi pada area sekitar crater Gunung Rajabasa, sedikit ke Barat Laut, selatan dan Barat Daya. Zona dengan tingkat kerapatan struktur yang tinggi pada area Gunung Rajabasa mengindikasikan adanya zona lemah yang berkaitan dengan peristiwa dan aktivitas kegunungapian pada masa lalu.

Hal ini ditandai dengan dominasi zona lemah yang sebagian teridentifikasi di dekat area sisa/bekas kawah Gunung Rajabasa.Sementara itu untuk area manifestasi panas bumi yang ada di Gunung Rajabasa memiliki pola yang tidak sama antara manifestasi yang berada di utara dengan manifestasi di selatan terkait zona lemah hasil analisis FFD.

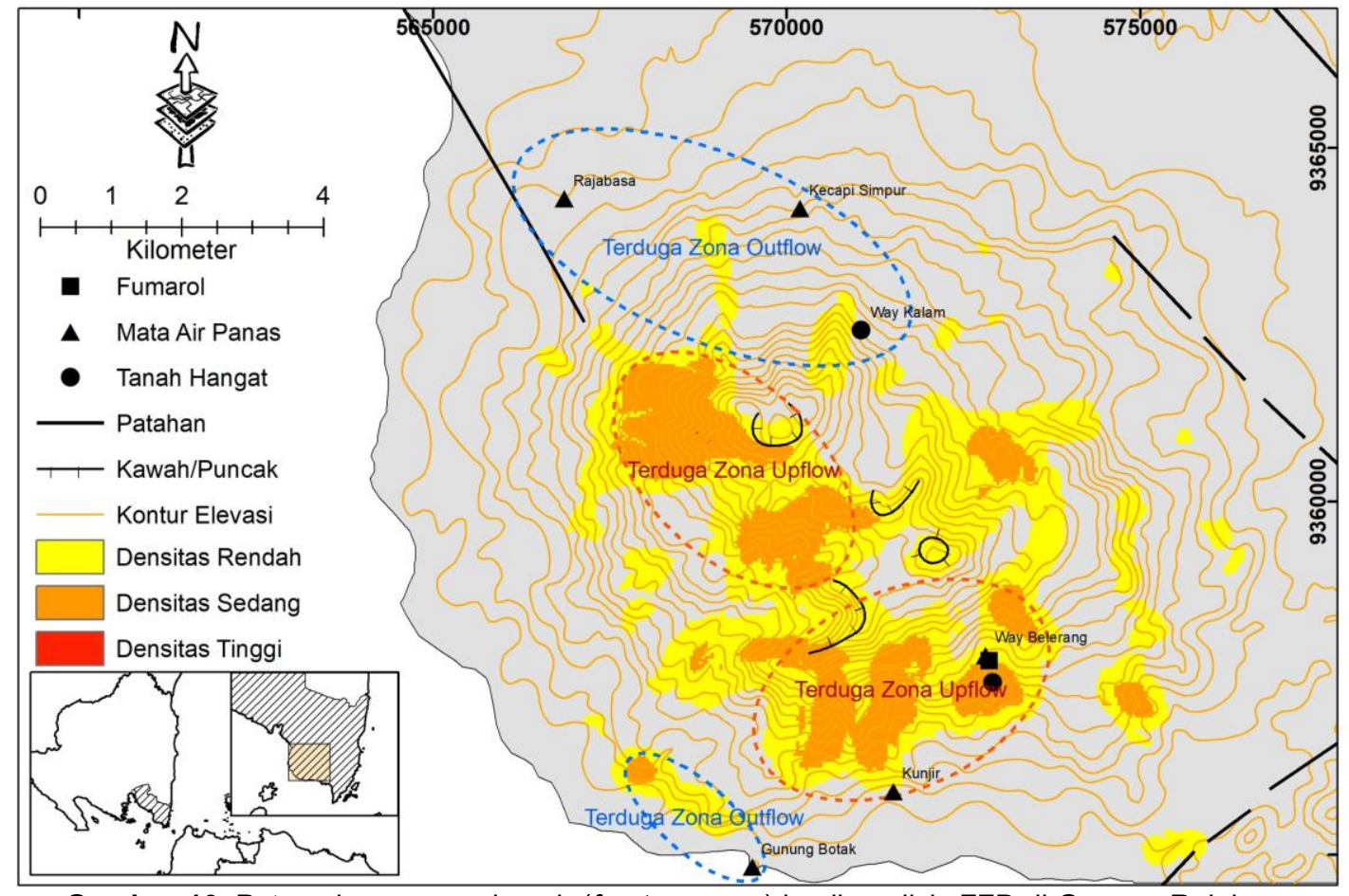

Gambar 10. Peta sebaran zona lemah (fracture zone) hasil analisis FFD di Gunung Rajabasa 
Area manifestasi di bagian Selatan seperti manifestasi mata air panas Kunjir dan fumarol Way Belerang berada pada zona lemah dengan tingkat kerapatan struktur yang cukup tinggi. Kondisi ini menunjukkan bahwa fluida panas bumi yang mengalir ke permukaan dan membentuk manifestasi panas bumi Kunjir dan Way Belerang berasal dari reservoar di sekitar manifestasi akibat zona lemah di wilayah tersebut. Bahkan posisi manifestasi Way Belerang yang berada tepat di atas zona lemah (fracture zone) yang diperkirakan sebagai zona reservoar selaras dengan tipe manifestasi asam berupa mata air panas, fumarol dan tanah hangat yang mencirikan manifestasi panas bumi pada zona upflow.

Pembentukan manifestasi panas bumi di zona upflow diakibatkan oleh adanya pemanasan air meteorik dangkal oleh fase uap fluida yang berasal dari reservoar panas bumi. Hasil pengamatan lapangan dan data sifat kimia fluida yang didominasi oleh unsur Sulfat (Kusumasari, 2011 dalam Darmawan dkk., 2015) menunjukkan ciri alterasi pada zona upflow di manifestasi Way Belerang. Sehingga, berdasarkan analisis tersebut, dapat diinterpretasikan bahwa zona lemah yang ditunjukkan dengan densitas struktur yang tinggi di area manifestasi Kunjir dan Way Belerang merupakan bagian dari zona reservoar panas bumi di Gunung Rajabasa.

Manifestasi lain yang teramati di lapangan adalah manifestasi air panas Gunung Botak yang terletak di pantai Wartawan, yaitu di kaki bagian Selatan Gunung Rajabasa tidak berada pada densitas struktur yang tinggi. Namun berdasarkan pengamatan data di lapangan menunjukkan bahwa mata air panas Gunung Botak bersifat netral dan terdapat siter silika. Kondisi ini menunjukkan bahwa manifestasi mata air panas Gunung Botak merupakan manifestasi panas bumi pada zona outflow. Interpretasi ini menunjukkan bahwa pada zona outflow, struktur yang terbentuk lebih dalam dan tidak intensif di permukaan. Hal ini dikarenakan fluida di zona outflow adalah fluida panas bumi yang berasal dari reservoar.
Oleh karena itu diperkirakan struktur yang membawa fluida ke manifestasi mata air panas Gunung Botak berasal dari reservoar melalui struktur bawah permukaan. Terkait posisi zona lemah di dekat Gunung Botak yang dapat diinterpretasikan sebagai zona reservoar atau berasal dari reservoar yang sama dengan manifestasi Kunjir dan Way Belerang masih dapat diperdebatkan sebagaimana konseptual model oleh Darmawan dkk., 2015 dan Kusumasari, 2011. Hasil ini menunjukkan bahwa metode FFD pada penelitian ini mampu mengidentifikasi zona lemah yang diinterpretasikan sebagai representasi zona reservoar panas bumi di permukaan. Meskipun pola struktur permukaan dan bawah permukaan dapat berbeda dan tidak terhubung/berkaitan pada kasus tertentu, pemanfaatan struktur kekar di permukaan masih dapat digunakan untuk mengidentifikasi zona lemah akibat struktur yang tampak di permukaan.

\section{KESIMPULAN}

Berdasarkan hasil penelitian dan pembahasan yang telah dilakukan, maka dapat disimpulkan bahwa hasil ekstraksi lineament dan FFD pada empat sudut azimuth menunjukkan bahwa arah dominan dari struktur yang teridentifikasi sebagian selaras dan searah dengan Sistem Sesar Sumatra dan sebagian menunjukkan respons yang memotong sistem sesar utama. Kenampakan struktur kekar di lapangan Gunung Rajabasa didominasi oleh arah Barat Laut Tenggara dengan pola kekar tektonik yang saling memotong dari tiga arah.

Hasil analisis FFD juga menunjukkan keterkaitan yang cukup signifikan antara zona lemah (fracturing) dengan zona reservoar panas bumi, yang ditunjukkan oleh pola zona upflow pada densitas struktur tinggi di manifestasi Way Belerang, dan zona outflow di manifestasi mata air panas Gunung Botak. Penelitian ini perlu dilanjutkan dengan memanfaatkan analisis FFD pada data geofisika bawah permukaan seperti data gravity dan magnetik agar pola struktur bawah 
permukaan dapat diidentifikasi dengan baik.

\section{UCAPAN TERIMA KASIH}

Terima kasih kepada Alaska Satellite Facility (ASF) Distributed Active Archive Center (DAAC) untuk akses terbuka seluruh data DEM ALOS PALSAR yang digunakan dalam penelitian ini. Penulis juga mengucapkan terima kasih kepada Laboratorium Geofisika Eksplorasi Jurusan Teknik Geofisika Universitas Lampung dan rekan-rekan yang telah membantu dalam penulisan artikel ini.

\section{DAFTAR PUSTAKA}

Barber, A.J., Crow, M.J., Milsom, J.S., 2005. SUMATRA: Geology, Resources and Tectonic Evolution. The Geological Society, London.

Bronto, S., Asmoro, P., Hartono, G., Sulistiyono, S., 2012. Evolution of Rajabasa Volcano in Kalianda Area and Its Vicinity, South Lampung Regency. Indones. J. Geosci. 7, 1125.

https://doi.org/10.17014/ijog.v7i1.132

Budiardjo, B., Masdjuk, Leonardus, A.M.N., 1995. Detailed Geological report Rajabasa Mountain area, Lampung.

Bujung, C.A.N., Singarimbun, A., Muslim, D., Hirnawan, F., Sudradjat, A., 2011. Identifikasi prospek panas bumi berdasarkan Fault and Fracture Density ( FFD ): Studi kasus Gunung Patuha , Jawa Barat. J. Lingkung. dan Bencana Geol. 2, 67-75.

Chemong, C.A., Chenrai, P., 2013. Fracture density analysis in the sai yok fault, western thailand and its implications for hydrological exploration. Res. J. Appl. Sci. 8, 125130. https://doi.org/10.3923/rjasci. 2013.125.130.

Darmawan, I.G.B., Setijadji, L.D., Wintolo, D., 2015. Geology and Geothermal System in Rajabasa Volcano South Lampung Regency, Indonesia (Approach to Field Observations, Water Geochemistry and Magnetic Method), in: Proceedings World Geothermal Congress.
Darmawan, I.G.B., Setijadji, L.D., Wintolo, D., 2013. Interpretasi Geologi Gunung Rajabasa Berdasarkan Integrasi Citra Aster, DEM dan Geologi Permukaan, in: Prosiding Seminar Nasional Kebumian Ke-6. hal. 285-298.

Das, A., Agrawal, R., Mohan, S., 2015. Topographic correction of ALOSPALSAR images using InSAR-derived DEM. Geocarto Int. 30, 145-153. https://doi.org/10.1080/10106049.201 4.883436 .

Kusumasari, B.A., 2011. Geology surrounding areas Waymuli geochemical geothermal fluid in Mountain Rajabasa, South Lampung Regency, Lampung Province. Skripsi, Institut Teknologi Bandung.

Liu, J.G., Mason, P.J., 2013. Essential image processing and GIS for remote sensing, Essential Image Processing and GIS for Remote Sensing. wiley. https://doi.org/10.1002/97811186879 63.

Mangga, S.A., Amirudin, Suwarti, T., Gafoer, S., Sidarto, 1993. Geological Map of Tanjungkarang, Sumatra. Geological Research and Development Centre, Bandung.

Rosenqvist, A., Shimada, M., Suzuki, S., Ohgushi, F., Tadono, T., Watanabe, M., Tsuzuku, K., Watanabe, T., Kamijo, S., Aoki, E., 2014. Operational performance of the ALOS global systematic acquisition strategy and observation plans for ALOS-2 PALSAR-2. Remote Sens. Environ. 155, 3-12. https://doi.org/10.1016/j. rse.2014.04.011.

Samsonov, S., 2010. Topographic correction for ALOS PALSAR interferometry. IEEE Trans. Geosci. Remote Sens. 48, 3020-3027. https://doi.org/10.1109/TGRS.2010.2 043739.

Shimada, M., Itoh, T., Motooka, T., Watanabe, M., Shiraishi, T., Thapa, R., Lucas, R., 2014. New global forest/non-forest maps from ALOS PALSAR data (2007-2010). Remote Sens. Environ. 155, 13-31. https://doi.org/10.1016/j.rse.2014.04. 014. 


\section{MAKALAH ILMIAH}

Suryantini, Wibowo, H., 2010. Application of Fault and Fracture Density (FFD) Method for Geothermal Exploration in Non-Volcanic Geothermal System; a Case Study in Sulawesi-Indonesia, in: Proceedings World Geothermal Congress 2010 Bali, Indonesia. hal. 1-9.

Tripp, G.I., Vearncombe, J.R., 2004. Fault/fracture density and mineralization: A contouring method for targeting in gold exploration. J. Struct. Geol. 26, 1087-1108. https://doi.org/10.1016/j.jsg.2003.11.0 02 .
Whittle, M., Quegan, S., Uryu, Y., Stüewe, M., Yulianto, K., 2012. Detection of tropical deforestation using ALOSPALSAR: A Sumatran case study. Remote Sens. Environ. 124, 83-98. https://doi.org/10.1016/j.rse.2012.04. 027.

$\begin{array}{ll}\text { Diterima } & : \text { 11 Januari } 2021 \\ \text { Direvisi } & : 21 \text { Juni } 2021 \\ \text { Disetujui } & : 27 \text { Agustus } 2021\end{array}$

